\title{
Chapter 7: \\ Indigenous peoples and climate change in Cameroon
}

\author{
Daniel Armel Owona Mbarga
}

Climate change is defined as modifications of the climate attributed directly or indirectly to human activity that alters the global atmosphere, contributing to natural climate variability over comparable time periods. ${ }^{1}$ These changes are a reality. Indeed, the recurrence of extreme weather events ${ }^{2}$ around the world is evidence of the fact that a gradual alteration of the climate system is happening. Proven or potential impacts are increasingly evident as a result of global warming, which are both harmful to humans and global ecosystems. ${ }^{3}$

Cameroon has also been affected by these climatic changes as evidenced in the various agro-ecological zones. ${ }^{4}$ There have been floods, recurrent droughts, strong winds, heavy rainfall and significant annual water variations. ${ }^{5}$ In addition, rising temperatures have increased evapotranspiration, leading to more frequent storms. ${ }^{6}$ The most devastating cases occurred in 2000, 2003 and 2007 in the coastal highlands of the south west of the country, causing US\$ 450,000 worth of damage. ${ }^{7}$

1 Article 1, United Nations Framework Convention on Climate Change of 9 May 1992.

2 Among the extreme events caused by climate change we have heat waves, droughts, floods, cyclones and forest fires. See IPCC (2014: 8).

3 Ibid: 4.

4 These are zones defined according to their ecological, climatic and edaphic characteristics. There are five in Cameroon, namely the Sudano-Sahelian zone, the high Guinean savannah zone, the highlands zone, the forest zone with bimodal rainfall, the coastal area with monomodal rainfall. The first is characterised by savannahs, steppes and an arid climate. The North and Far North Regions are part of this zone. The high Guinean savannah zone, on the other hand is considered as the country's first watershed because a good number of major rivers take their rise from here. The Centre Region, the Sudano-Guinean savannah and the Adamawa plateau are part of this zone. The Upper plateau zone for its part includes the West and North West Regions. It is also considered as the country's second watershed. The forest zone with a bimodal rainfall includes the East and South Regions. In addition, it is a tropical forest particularly characterised by a dense hydrographical network. Finally, the coastal area with a mono-modal rainfall includes the coastal and mountainous zone with a humid equatorial climate. See Ministry of the Environment, Nature Protection and Sustainable Development (2015).

5 Ministry of Environment, Nature Protection and Sustainable Development (2015: 2; 23-24).

6 Ibid: 38 .

7 Ibid. 
Such phenomena are obviously not without consequences for Cameroon's population. Over the last 20 years, floods have affected more than 90,000 people and killed more than 100 throughout the country. ${ }^{8}$ In the Sudano-Sahelian agro-ecological zone, in particular, ${ }^{9}$ floods killed 153 people in 2011 and 2012. ${ }^{10}$ Heat waves in this zone greatly increase the risk of mortality, food insecurity and famine as well as skin and other diseases such as malaria and others. ${ }^{11}$ In the coastal zone with mono-modal rainfall, the amount and variability of rainfall greatly increased the risk of death from water-borne diseases. ${ }^{12}$

Future predictions concerning the effects of climate change in Cameroon are equally disturbing. According to the National Plan for Adaptation to Climate Change (PNACC), it is predicted that an average of five droughts per decade may cause at least 500 deaths in the Sudano-Sahelian zone. ${ }^{13}$ This serves as an example for the growing gravity of the consequences of climate change on human beings.

Climate related impacts are particularly alarming for vulnerable groups such as indigenous peoples. ${ }^{14}$ Indigenous peoples are expected to be more and more affected by climate change because their livelihoods largely depend on land use and natural resources. ${ }^{15}$ At the same time, they are among those who have least contributed to carbon emissions. ${ }^{16}$

To date, there is no internationally accepted definition of the term 'indigenous peoples'. As proof, the United Nations Declaration on the Rights of Indigenous Peoples adopted by the General Assembly on 13 September 2007 does not define the term. This is because there is no comprehensive definition that embodies the current diversity of cultures, history and circumstances of indigenous peoples. ${ }^{17}$ It is for this reason that the organisations that represented indigenous people during the development of the above-mentioned United Nations declaration explicitly rejected any definition of who they were. ${ }^{18}$ As Kobila stated, we "notice the inappropriateness to define the concept of indigenous peoples". ${ }^{19}$ Thus, in order to identify indigenous peoples, it is

8 Ibid.

9 With its mono-modal rainfall the coastal zone is one of the areas most vulnerable to climate change. See Ministry of the Environment, Nature Protection and Sustainable Development (2015: 49).

10 Ministry of the Environment, Nature Protection and Sustainable Development (2015: 39).

11 Ibid: 48.

12 Ibid: 44.

13 Ibid: 41.

14 The Cameroonian Government acknowledges the existence of vulnerable indigenous peoples in the country. See $<$ http://www.minas.cm/index.php?option=com_content\&view=article\&id= $157 \&$ Itemid $=183 \&$ lang=fr $>$ (accessed 4-3-2018).

$15 \operatorname{IUCN}(2010: 2)$.

16 Ibid.

17 Centre for Minority Rights Development (Kenya) and Minority Rights Group (on behalf of Endorois Welfare Council) v. Kenya 276/03 (2009: 18).

18 Geslin (2010: 7).

19 See Kobila (2009: 28). 
necessary to refer to various criteria established at the universal, regional and national levels.

At the universal level, Martinez Cobo's study of "the Problem of Discrimination against Indigenous Peoples", prepared under the auspices of the United Nations, identifies precedence over a given territory before colonisation, non-dominance and marginalisation from an economic, political and socio-cultural point of view, as well as the claim of one's own identity, as distinct criteria. ${ }^{20}$

At the regional level, through its Working Group on Indigenous Populations/Communities, the African Commission on Human and Peoples' Rights notes that certain criteria such as precedence set out in Cobo's study are unworkable in the African context. ${ }^{21}$ Indeed, except in specific cases such as the San people in southern Africa and the Pygmies in central Africa, all Africans are indigenous because they have always lived in this territory. ${ }^{22}$ Therefore, the African Commission advocates that the identification of indigenous peoples should be based on selected criteria taking the African context into consideration. These include: ${ }^{23}$

- $\quad$ self-definition as indigenous peoples distinct from other groups within a State;

- $\quad$ special attachment to and use of their traditional heritage by which their ancestral lands and territories are of crucial importance to their physical and cultural survival; and

- experience of subjugation and marginalisation because of their culture, lifestyle or ways of production, which differ from the hegemonic and dominant model of the national majority.

Based on these criteria, the African Court on Human and Peoples' Rights also established criteria, which it considers important for identifying indigenous peoples: ${ }^{24}$

The presence of priority in time with respect to the occupation and use of a specific territory; a voluntary perpetuation of cultural distinctiveness, which may include aspects of language, social organisation, religion and spiritual values, modes of production, laws and institutions; self-identification as well as recognition by other groups, or by State authorities that they are a distinct collectivity; and an experience of subjugation, marginalisation, dispossession, exclusion or discrimination, whether or not these conditions persist.

Finally, at the national level, even though Cameroon recognises subjective rights of indigenous peoples in the Preamble of its Constitution, its conception seems different from the one advocated at the universal level. It is the underlying conception used in this chapter hereinafter. It draws from the spirit and letter of Article 57(3) of the

20 Cameroon's Ministry of Forestry and Wildlife (2011:14).

21 African Commission on Human and Peoples' Rights Experts Working Group on Indigenous Populations / Communities (2005: 103).

22 Ibid.

23 Ibid: 103-104.

24 African Commission on Human and People's Rights v. Republic of Kenya Application No. 006/2012 (2017: 31). 
Constitution. According to this Article, the Regional Council is headed by an indigene elected from among its members for the life of the Council. The Constitution recognises the existence of indigenous peoples in each of the ten regions of the country. ${ }^{25}$ It holds that all people are indigenous to their land. ${ }^{26}$ As such, Cameroon gives this concept a meaning similar to that of the African Commission on Human and Peoples' Rights. However, only those indigenous peoples whose vulnerability has been established on account of their socio-economic status, as a result of historical injustices, are eligible to the special constitutional and international protection of indigenous peoples. ${ }^{27}$ This autochthony is in the same vein as that of the colonisers before independence. Indeed, since the time East Cameroon was a French-mandated territory under the League of Nations, the entire so-called native population was considered indigenous. Evidence of this can be found in an annual report submitted to the Council of the League of Nations at its sixth session between June and July 1925, in which the expression 'indigenous population' refers to people as listed below: ${ }^{28}$

In the three constituencies of Garoua, Maroua and Ngaoundere, we are dealing with a society where conquerors, whose organisation reminds of feudalism, are placed at the head of the indigenous population.

Some indigenous people considered as vulnerable include ${ }^{29}$ the Mbororo and Pygmies because their vulnerability to climate change is often raised. ${ }^{30}$ The Mbororo are nomadic Fulani known for their engagement in pastoral activity, ${ }^{31}$ who roam the bush in search of pastures. ${ }^{32}$ Estimated at more than 60,000 people, they are subdivided into three main groups, namely the Jafun, Woodabe and Aku. ${ }^{33}$ They are found throughout Cameroon but mainly in the north west, west, north, Adamawa and east regions. ${ }^{34}$ The Pygmies are considered as the first inhabitants of the African tropical forests and their lifestyle is based on hunting and gathering. ${ }^{35}$ They are mainly found in the east, south and central regions and in the southern part of the coastal zone. ${ }^{36}$ The Pygmies consist of three major groups: the Bakas, the Bagyelis and Bedzans. ${ }^{37}$

25 Kobila (2009: 100).

26 Ibid: 99.

27 Ibid: 100.

28 France (1925: 54).

29 The author agrees with Kobila (2009: 102) that establishing a limited list of vulnerable indigenous populations does not coincide with the understanding of the Cameroonian Constitution in its Article 57(3).

30 See Nguegang Tayou (2017) and the Project: Population Resilience to Climate Change, funded by the United Nations Development Programme.

31 Mouiche (2012: 152).

32 Ibid: 153.

33 Nguiffo \& Mballa (2009: 1).

34 Mouiche (2012: 153).

35 Ibid.

36 Nguiffo \& Mballa (2009: 1-2).

37 Ibid. 
Indigenous marginalisation has been evidenced by historical exclusion from decision-making processes and by the fact that they are often pushed into resource-poor and climate-sensitive regions because of development activities. ${ }^{38}$ When combined with the effects of climate change, their vulnerability is exacerbated.

Cameroonian climate policy must, therefore, take indigenous peoples into account in order to protect them against the impacts of climate change. The State of Cameroon is also obliged to do so in light of its legal obligation as a signatory to the Paris Agreement. ${ }^{39}$ Article 7 of this Agreement stipulates that parties should take into account and draw on the best available scientific knowledge and, as appropriate, traditional knowledge, indigenous know-how and knowledge and local knowledge systems, to adapt relevant socio-economic and environmental policies and measures. Hence, it is necessary to examine the level of protection of indigenous populations in Cameroon's climate policy.

Despite the existence of several articles focusing on indigenous populations in Cameroon, ${ }^{40}$ these writings do not address the issue of climate change. Thus, this chapter attempts to progress research on this particular topic by evaluating the level protection of indigenous populations in light of the growing impacts of climate change.

\section{Little initial consideration of the indigenous populations}

Cameroon signed and ratified the United Nations Framework Convention on Climate Change (UNFCCC) ${ }^{41}$ which represents the instrument that formalises the international legal system on climate change. Cameroon's climate policy reveals that indigenous people have been accorded a far more central role in recent times. Between 1996 and 2005, Cameroon has developed several planning documents pertinent to climate change including the National Environmental Management Plan (NEMP) of February 1996 and Cameroon's First Initial National Communication to the UNFCCC in 2005. These documents reveal an undifferentiated participation of indigenous peoples not only in the preparation phase but also regarding the proposed response strategies.

$38 \operatorname{IUCN}(2010: 2)$.

39 Cameroon ratified the Paris Agreement on 29 July 2016. See <https://www.ecolex.org/> (accessed 10-12-2017).

40 See for example Abega (1996-1997); Abega \& Bigombe Logo (2006); Atsiga Essala (1999); Bigombe Logo (2000).

41 Signature in 1992 and retification in 1994; the Convention entered into force in Cameroon on 17 January 1995. See <https://www.ecolex.org/details/treaty/united-nations-framework-convention-on-climate-change-tre-001147/?q=Convention+cadre + des + Nations+Unies + sur + les + changements + climatiques $>$ (accessed 10-12-2017). 
2.1 Undifferentiated participation of indigenous peoples in the development of strategy papers on climate change

Strategy or planning papers are usually developed after consultation with various stakeholders, including experts, members of government, donors and private persons, who can intervene at various stages of the process. With the aim of developing policies, strategies and actions for the protection of the environment and the rational management of natural resources for sustainable development, ${ }^{42}$ the NEMP reflects Cameroon's climate-related aspirations. The strategy was developed in line with the expectations under the UNFCCC..$^{43}$ It was also developed with the participation of the populations concerned, such as rural and urban communities, the government and the public service, specialised non-governmental organisations, professional associations, and all users of natural resources, including forests and pastures as well as donors and international cooperation agencies. ${ }^{44}$ Although indigenous peoples have not been mentioned explicitly, it can be deduced that they had been included in the general reference 'users of natural resources' since Pygmies use forests and Mbororos rely on pastures, which are both natural resources.

\subsection{Lack of differentiation of the indigenous peoples in the response strategies developed}

The state of vulnerability of the population should be assessed also taking into account the potential variability of the impacts of climate change on urban dwellers and indigenous populations, particularly as regards to the way they can cope or adapt to these changes. Cameroonian responses developed to address the effects of climate change envisage mitigation and adaptation. The former refers to measures that contribute to the reduction of the negative impacts of climate change, while the latter refers to measures that contribute to the modifications of lifestyles in a bid to cope with the consequences of climate change. Various measures proposed in the initial national communication shall mitigate the growth of greenhouse gases in the forestry sector. These include the reduction of emissions from biomass use, the expansion of sequestration sinks of forest emissions and the change in land use. ${ }^{45}$

As concerns adaptation to the adverse effects of climate change, the initial national communication takes into account the strategies used by farmers in the Benue Valley, particularly the change in cultivation practices, the constitution of safety stocks, the

42 Ministry of the Environment and Forests (1996: 6).

43 For the analysis of incentives particularly financial, that moved Cameroon to include climate change in its political agenda, see Kede (2017).

44 Ibid: 6. See also Ministry of the Environment and Forests (1996: 6).

45 Ministry of the Environment and Forests (2005: 71). 
change of date for certain operations and the use of new plots. ${ }^{46}$ Upon observation, it is noticeable that the response strategies proposed in the initial national communication do not include indigenous peoples. Yet, these strategies should take into account traditional knowledge of indigenous peoples as they possess knowledge capable of facilitating adaption to climate risks. ${ }^{47}$ This is, for instance, the case for mixed cropping or higher crop diversification on the same plot. The objective of this strategy is not only to reduce crop vulnerability but to multiply the quality of plants in the field. Thus, if some of the plants are not resistant to variations due to climate change, the others may be. ${ }^{48}$ This allows Pygmies to adapt to climate disruptions. ${ }^{49}$ In addition, the traditional system of forecasting the beginning and the end of the rainy season can be seen as another asset of traditional knowledge. The Baka, for instance, determine the beginning of the rainy season based on the first appearance of edible black head caterpillars. ${ }^{50}$ Rains usually start exactly two weeks after the appearance of these caterpillars. ${ }^{51}$ This makes it possible to adapt to irregular rainy seasons due to climate change.

Thus, between 1996 and 2005, the potential participation of indigenous people in the fight against climate change was not taken into account. Yet, they could make a significant contribution in this area. It is undoubtedly for this reason that Cameroon's climate policy has recently given greater importance to these populations.

As from 2012, it is noticeable that indigenous people have been more and more integrated into Cameroon's climate policy consultation processes. In fact, a careful observation of documents such as the National Adaptation Plan (PNACC) ${ }^{52}$ of 24 June 2015, the 2015 planned determined contribution at the national level and the 2012 proposed measures for the state of preparedness (R-PP), show governmental recognition of the contribution of indigenous peoples in the development of climate strategy papers, as well as the consideration of their vulnerability in proposed responses.

46 Ibid: $94-95$.

47 World Bank (2010: 108).

48 Fosso (2014).

49 Ibid.

50 Ibid.

51 Ibid.

52 The national plan on Adaptation to Climate Change is a national strategy paper, which is aimed at guiding the government and stakeholders in approaching adaptation to climate change. See Ministry of Environment, Nature Protection and Sustainable Development (2015: 27). 
3.1 Government recognition of the contribution of indigenous peoples in the development of climate strategy papers

The recognition of the contribution of indigenous peoples in the preparation of strategy papers in the fight against climate change is the result of the internalisation of international commitments to which Cameroon has subscribed. In developing its PNACC, for example, Cameroon has followed the UNFCCC recommendations as well as those of the Cancun Framework for Adaptation,,$^{53}$ taking into account and drawing on traditional and indigenous approaches.

Furthermore, the proposal for the state of preparedness measures (R-PP) within the framework of the mechanism on reducing emissions from deforestation and forest degradation $(\mathrm{REDD}+)$ states that indigenous peoples are among the 21 members of the REDD+ Steering Committee. ${ }^{54}$ This Committee is responsible for planning policy and strategy proposals for the REDD+ initiative, developing selection criteria for the projects that shall be submitted to the Minister in charge of the environment, and validating the work and approving the action plan of the Technical Secretariat. ${ }^{55}$ They, therefore, play a major role in the decision-making process on climate. In addition, the participation of indigenous peoples is evaluated at $7 \%$ in the regional and national consultation workshops for the finalisation of the R-PP. ${ }^{56}$ This involvement is explained by the relevance of indigenous peoples in the REDD+ framework and the choice Cameroon has made to develop a REDD+ mechanism that particularly targets the development of vulnerable groups. ${ }^{57}$

\subsection{Taking into account the vulnerability of indigenous peoples in proposed} response strategies

As part of recommendations for the sectoral policy, the PNACC takes into account the vulnerability of the indigenous populations in terms of gender, vulnerability, social protection and national solidarity sectors. The objective here is to reduce the vulnerability of marginalised populations and to build their capacities, autonomy and independence. ${ }^{58}$ The PNACC also recommends the development of a specific plan to support indigenous peoples in the event of disaster. ${ }^{59}$

53 Ministry of Environment, Nature Protection and Sustainable Development (2015: 27).

54 Republic of Cameroon (2012: 11).

55 Ibid.

56 Ibid: 18.

57 Ibid.

58 Ministry of Environment, Nature Protection and Sustainable Development (2015: 80).

59 Ibid: 81. 
In addition, the PNACC also takes into account the vulnerability of indigenous peoples within the framework of its proposed projects. An example is a project focusing on the improvement of local governance structures in response to climate change, to strengthen local mechanisms for securing the rights of use and access to land ownership for the main stakeholders, particularly indigenous peoples. ${ }^{60}$ The nationally determined contribution (NDC) of Cameroon projects to build capacities of indigenous peoples, within the framework of adaptation measures. ${ }^{61}$ This shows the growing role that indigenous peoples are playing in contemporary Cameroonian climate policy.

\section{Conclusion}

While in the past, the capacity of indigenous peoples in Cameroon's climate policy was underutilised and underrepresented, in recent years, they have been more and more integrated into the Cameroonian climate policy and strategy. This happened for good reasons: First, the influence of Cameroon's international commitments towards a greater inclusion of indigenous peoples in climate change planning. Secondly and perhaps even more important, the realisation of the value that indigenous and traditional knowledge can play in overcoming their vulnerability in the implementation of concrete projects.

\section{References}

Abega, SC (1996-1997) La communication avec les Pygmées Baka.

Abega, SC \& P Bigombe Logo (eds) (2006) La marginalisation des Pygmées d'Afrique centrale.

African Commission's Working Group of Experts on Indigenous Populations/Communities (2005) Rapport du Groupe de travail d'experts de la Commission africaine des droits de l'homme et des peuples sur les populations/communautés autochtones, at $<$ https://www.iwgia.org/images/publications//African_Commission_book_French.pdf $>$ (accessed 20-7-2018).

Atsiga Essala, L (1999) “L'exploitation des populations marginales : le cas des Pygmées du Cameroun" 2 Les formes contemporaines d'esclavage, Cahier africain des droits de l'homme 155-177.

Bigombe Logo, P (2000) "Droits des peuples autochtones au Cameroun: le dilemme de la reconnaissance et de la banalisation" 37 Bulletin IKEWAN 9-11.

Fosso, LC (2014) Stratégies indigènes d'adaptation aux changements climatiques: cas des populations autochtones et communautés locales autour du parc national de Boumba Bek, Est Cameroun Dissertation University of Dschang.

France (1925) Rapport annuel du Gouvernement français sur l'administration sous mandat des territoires du Cameroun pour l'année 1924.

60 Ibid: 110.

61 Republic of Cameroon (2015: 15). 
Geslin, A (2010) La protection internationale des peuples autochtones : de la reconnaissance d'une identité transnationale autochtone à l'interculturalité normative Annuaire français de droit international.

IPCC / Intergovernmental Panel on Climate Change (2014) Changements climatiques 2014. Rapports de synthèse. Résumé à l'intention des décideurs, at <http://www.ipcc.ch/pdf/assessment-report/ar5/syr/AR5_SYR_FINAL_SPM_fr.pdf> (accessed 20-7-2018).

IUCN / International Union for Nature Conservation (2010) Indigenous peoples and REDD-plus. Challenges and opportunities for the engagement of indigenous peoples and local communities in REDD-plus, at $<\mathrm{https} / / \mathrm{www} . \mathrm{iucn}$. org/downloads/a4_iucn_indigenous_peoples_and_redd_pdf $>$ (accessed 20-7-2018).

Kede EY (2017) La gouvernance climatique au Cameroun. Sociologie d'une action publique internationale en contexte africain.

Kobila JM (2009) La protection des minorités et des peuples autochtones au Cameroun. Entre reconnaissance interne consacrée et consécration universelle réaffirmée.

Ministry of Environment and Forests (1996) Plan national de gestion de l'environnement, at $<$ http://api.commissiemer.nl/docs/cms/O83_032_detb_PNGEVOL1.pdf > (accessed 20-7-2018).

Ministry of Environment and Forests (2005) Communication nationale initiale, at $<\mathrm{http} / / \mathrm{un}$ fccc.int/resource/docs/natc/cmrnc1f.pdf> (accessed 20-7-2018).

Ministry of Environment, Nature Protection and Sustainable Development (2015) Plan national d'adaptation aux changements climatiques $d u$ Cameroun, at $<\mathrm{http} / / \mathrm{www} 4 . u n f c c c . i n t / \mathrm{nap} /$ Documents/Parties/PNACC_Cameroun_VF_Valid\%C3\%A9e_24062015\%20-\%20FINAL.pdf> (accessed 20-7-2018).

Ministry of Forests and Wildlife (2011) Projet de conservation et d'utilisation durable de la forêt de Ngoyla-Mintom. Plan pour les peuples autochtones et vulnérables (PPAV), at $<\mathrm{http}: / / \mathrm{www} . \mathrm{min}-$ fof.cm/documentation/Ngoyla-Mintom-PPAV\%20-\%20Final.pdf $>$ (accessed 20-7-2018).

Mouiche, I (2012) Démocratisation et intégration sociopolitique des minorités ethniques au Cameroun: Entre dogmatisme du principe majoritaire et centralité des partis politiques.

Nguegang Tayou, SA (2017) Genre et vulnérabilité des peuples autochtones au changement climatique : cas des Mbororo du Cameroun Dissertation Catholic University of Louvain.

Nguiffo, S \& N Mballa (2009) Les dispositions constitutionnelles, législatives et administratives relatives aux populations autochtones au Cameroun, at $<\mathrm{http}$ //docplayer.fr/68592794-Les-dispositions-constitutionnelles-legislatives-et-administratives-relatives-aux-populations-autochtones-aucameroun-samuel-nguiffo-et-nadine-mballa.html> (accessed 20-7-2018).

Republic of Cameroon (2012) Readiness preparation proposal ( $R-P P$ ), at $<\mathrm{https}$ ://www.forestcarbonpartnership.org/sites/fcp/files/Documents/PDF/Oct2012/Cameroon\%20final\%20R-PP-EnglishOctober\%2C\%202012.pdf> (accessed 20-7-2018).

Republic of Cameroon (2015) Contribution prévue déterminée au niveau national, at $<$ http://www4.unfccc.int/ndcregistry/PublishedDocuments/Cameroon\%20First/CPDN\%20CMR\%20Final.pdf> (accessed 20-7-2018).

United Nations Permanent Forum on Indigenous Issues (2008) Climate change and indigenous peoples, at $<\mathrm{http}: / / \mathrm{www} . u n . o r g /$ en/events/indigenousday/pdf/Backgrounder_ClimateChange_FINAL.pdf $>$ (accessed 20-7-2018).

World Bank (2010) Nouveaux horizons. Développement et changement climatique. 